\title{
Articulatory Consistency for Differential Diagnosis of Speech Sound Disorders
}

\author{
Seunghee $\mathrm{Ha}^{\mathrm{a}}$, Dong Gi Seo ${ }^{\mathrm{b}}$ \\ ${ }^{a}$ Division of Speech Pathology and Audiology, Audiology and Speech Pathology Research Institute, Hallym University, Chuncheon, Korea \\ ${ }^{b}$ Department of Psychology, Hallym University, Chuncheon, Korea
}

\author{
Correspondence: Seunghee $\mathrm{Ha}, \mathrm{PhD}$ \\ Division of Speech Pathology and Audiology, \\ Audiology and Speech Pathology Research \\ Institute, Hallym University, 1 Hallimdaehak-gil, \\ Chuncheon 24252, Korea \\ Tel: $+82-33-248-2215$ \\ Fax: +82-33-256-3420 \\ E-mail: shha@hallym.ac.kr
}

Received: October 5, 2019

Revised: November 3, 2019

Accepted: November 4, 2019

This research has been supported by Hallym University Research Fund (No. HRF-201909-015).
Objectives: This study aimed to examine developmental patterns of articulatory consistency in typically developing children and children with speech sound disorders, and to identify a cutoff score for differentiating between normal variation and inconsistent productions. Methods: This study included 524 children aged between 2;0 and 9;11. They were asked to produce 22 words on three separate occasions. Consistency scores were calculated based on the phonetic transcription of each response. Statistical analyses were performed to investigate whether consistency was different across age groups between typically developing children and children with speech sound disorders and to identify a cutoff score for differentiating inconsistency from normal variation. Results: The results showed that there were significant main effects and no interaction effect between age and groups. Both typically developing children and children with speech sound disorders showed higher accuracy and consistency of articulation as they grow up. In particular, consistent scores of 4- to 6-year-old children were significantly higher than those of 2-and 3-year-old children. Children's word productions were highly consistent at 4.5 years of age. This study suggested that a cutoff score of 27 could be used to differentiate inconsistent speech sound disorders from typical speech sound development and other types of speech sound disorders. Conclusion: This study suggested a foundation for differential diagnosis of speech sound disorders. Further investigations are needed to test the sensitivity and specificity of the cutoff score for differential diagnosis of speech sound disorders.

Keywords: Speech sound disorders, Differential diagnosis, Articulatory consistency, Inconsistent speech disorders, Consistent scores, Cutoff scores
말소리를 습득하는 초기 단계에 있는 1 세 아동에게는 동일한 낱 말을 서로 다른 형태로 산출하는 변이적인 특성이 자주 관찰된다 (Holm, Crosbie, \& Dodd, 2007; Sosa, 2015; Sosa \& Stoel-Gammon, 2006). Dyson과 Paden (1983)은 이러한 변이적인 산출을 아 동의 음운습득전략의 하나로서 성인의 목표낱말에 근접한 형태로 산출하고자 하는 시도로서 해석하기도 하였다. 조음변이성은 말. 운동학적, 음운론적 미성숙으로 인해 발생한다고 일반적으로 해석 하지만, 아동의 말 체계가 점차 성인의 체계로 나아가고 있음을 의 미하는 긍정적인 해석도 가능하다(Grunwell, 1992; Holm et al., 2007). 따라서 낱말이나 음소 수준에서의 변이적인 산출은 아동의
연령과 함께 조음정확도가 증가할수록 감소하는 발달적 경향성을 보인다. 예를 들어, 2-3세 일반아동을 대상으로 종단연구를 진행한 McLeod와 Hewett (2008)은 아동의 자발화에서 반복한 낱말의 약 $50 \%$ 가 변이적인 산출 형태를 보였으며, 3 세가 되면 정확도는 증가 하고 변이성은 감소하여 일관적인 산출을 보인다고 보고하였다.

조음변이성은 일반적인 조음음운 발달 과정 중 일시적으로 나타 나는 특성이면서 동시에 병리적인 말소리장애를 진단할 수 있는 표 지(diagnostic marker)로도 의미가 있다. 과거에는 뚜렷한 원인이 없이 말소리 산출상의 어려움을 보일 경우 '기능적인 조음장애'라 는 용어를 사용했지만 현재에는 말소리 문제를 일으키는 근본적인 
원인이 정확하게 밝혀지지 않았을 뿐 기저의 원인이 존재한다는 믿 음 하에 '원인을 알 수 없는 말소리장애(speech sound disorders with unknown origin)'라는 용어를 사용하고 있다. 또한 심각도, 기저 원인, 증상 면에서 다양한 '원인을 알 수 없는 말소리장애'의 하위유형을 나누고자 하는 시도가 계속되고 있다. 그 중 Dodd (2005)는 표면오류패턴 또는 언어학적 증상을 기준으로 조음장애, 음운지연, 일관적인 음운장애, 비일관적인 음운장애로 말소리장 애 하위유형을 분류하였다. 이중 비일관적인 음운장애는 동일한 낱말을 서로 다른 형태로 산출하는 비일관성을 보인다. 또한 말운 동 프로그램상의 문제로 발생하는 아동기 말실행증도 비일관성이 진단의 핵심적인 특징 중 하나이다.

일부 말소리장애 학자들은 정상과 병리적인 조음변이성의 경계 를 변이성(variability)과 비일관성(inconsistency) 이라는 두 용어 를 사용하여 구분하고자 하였다(Dodd, 2005; Holm et al., 2007). 변이성은 음성적 문맥, 인지-언어학적 영향 등으로 정상적인 말소 리 습득 과정에 나타나는 자연스런 말 특성을 가리킨다. 반면에, 비 일관성은 발달 과정에서 관찰되는 변이성과는 양과 질적으로 다른 경우로서 예측하기 어려울 정도로 다양하고, 다수의 오류형태를 포함한다. 비일관성은 말 처리 과정상에서 더 광범위한 어려움과 관련이 있어 비일관적인 말 특성을 보이는 아동은 조음 문제와 함 께 언어와 읽기상의 문제를 복합적으로 보일 수 있다(Grunwell, 1981; Williams \& Stackhouse, 2000). 따라서 임상에서 정상 또는 지연 발달과 말소리장애를 구별하고, 말소리장애 하위유형을 감별 진단하기 위해서는 말소리 습득 과정에서 관찰되는 정상적인 변이 성과 병리적인 비일관성을 구분하고 판단할 수 있는 점수 체계와 기준점(cutoff score)이 필요하다.

Dodd (1995)는 3-6세 영국 아동들을 대상으로 25개의 낱말을 각각 세 번 산출하는 과제를 실시하고, 해당 과제의 표준화 연구결 과를 바탕으로 비일관적인 음운장애를 진단할 수 있는 기준점을 제시하였다. 연구대상자 중 가장 변이적인 산출을 보였던 3세 전반 아동의 변이성 점수 표준편차 2.5 를 바탕으로, 25 개 낱말 중 10 개 이상(40\%)의 낱말을 서로 다른 형태로 산출하면 비일관적인 말소 리장애로 분류하였다. 즉 검사어 중 $40 \%$ 이상을 서로 다른 형태로 산출한다면 연령에 상관없이 정상적인 수준을 넘어선 것으로 해석 하였다. 연구자들은 이 점수를 바탕으로 말소리장애의 하위유형을 나눈 결과, 전체 말소리장애 아동 중 약 $9 \%$ 가 비일관적인 말소리장 애로 분류되었으며, 언어학적 증상으로 분류한 말소리장애의 하위 유형 중 가장 작은 비율을 차지하였다(Broomfield \& Dodd, 2004). 이러한 선행연구는 모든 말소리장애 아동이 일반아동과 비교해서 산출의 일관성이 떨어지는 것이 아니고, 일부 말소리장애 아동만
이 병리적인 비일관성을 보임을 제시하고 있다. 하지만 비일관적인 말소리장애는 작은 비율로 출현하기는 하나, 음운계획, 음운인식, 읽기능력 등 여러가지 말.언어 능력면에서 더 큰 어려움을 보여, 다 른 말소리장애와는 구별된 다른 치료법이 필요하다(Dodd, 1995, 2005). 실제로 임상에서 일반적으로 사용하는 말운동 접근법에 기 반한 치료나 음운대조를 강조한 치료는 비일관적 음운장애로 진단 된 아동에게는 효과적이지 않았다(Dodd \& Bradford, 2000). 궁극 적으로 이러한 일련의 말소리장애 하위유형 분류와 분류기준에 대 한 연구는 말소리장애의 감별 진단과 차별적인 치료법 사용의 중요 성을 강조하고 있다.

한편 조음변이성에 대한 국내 연구를 살펴보면 먼저 Hwang과 $\mathrm{Ha}$ (2012)는 2세 후반과 4세 일반아동에게 2-4음절의 목표단어를 4 회씩 반복 산출하도록 한 후 조음변이성을 측정하였다. 연구결과, 2 세 후반과 3 세 전·후반 사이에 조음변이성이 감소하여 4 세에는 일관적인 산출 형태를 보였다. 또한 Kim과 $\mathrm{Ha}$ (2016)는 조음변이성 의 특징이 2 세에 두드러지게 나타남을 고려하여 24-36개월 아동의 자발화에 나타난 단어와 음소변이성을 살펴보았다. 연구결과, 2 세 전반에는 2 회 이상 산출한 어절 중 $51.55 \%$ 가 다양한 형태로 산출 되다가 2세 후반에는 $36.46 \%$ 로 단어변이성이 감소하였다. 3-6세 일반아동과 4-5세 순수 말소리장애를 대상으로 조음복잡성 정도 에 따라 조음변이성을 살펴본 $\mathrm{Han}$ 과 $\mathrm{Ha}$ (2017)에서는 일반아동은 연령이 증가함에 따라 조음변이성이 감소하였고, 조음복잡성이 높 을수록 일반과 말소리장애 아동 모두 변이성이 증가하였다.

임상현장에서 비일관적인 말 산출 문제를 평가하고 확인하여 말 소리장애 진단에 적용하기 위해서는 표준화된 규준 자료를 토대로 정상적인 변이성과 구별하여 병리적인 비일관성을 진단할 수 있는 점수 체계와 기준점이 필요하다. 이러한 점수 체계와 규준 자료에 기초한 기준점은 말소리장애의 단순한 진단뿐만 아니라 말소리장 애의 특성과 본질을 좀 더 세부적이고 깊게 이해하는 과정의 기초 를 이룰 것이다. 본 연구는 일반아동과 말소리장애 아동으로부터 수집한 표준화 자료를 바탕으로 변이성이 점차 사라지고 일관적인 조음패턴을 이루는 발달 과정을 살펴보고, 말소리장애 평가에서 비일관적인 특성을 보이는 아동을 감별 진단할 수 있는 기준을 제 시하고자 하였다. 구체적으로 정상적인 변이성과 병리적인 비일관 성의 경계를 구분하는 점수 체계로서 조음 일관성을 나타내는 점 수를 제안하고, 일반아동과 말소리장애 아동의 조음 일관성 특징 을 살펴보고자 한다. 집단과 연령에 따라 일관성 점수가 어떠한지 살펴보고, 비일관적 말소리장애로 진단할 수 있는 기준점을 찾아 보고자하였다. 


\section{연구방법}

\section{대상자}

본 연구는 서울, 경기, 강원, 충청, 경상, 전라 지역에 거주하는 2 세 0개월에서 9세까지 아동 524명(남 291명, 여 233명)을 대상으로 실시하였다. 말소리 습득이 6세에 일반적으로 완성되는 점을 고려 하여(Ha, Kim, Kim, \& Shin, 2019; Ha, Kim, \& Pi, 2019; Kim, 1996; $\operatorname{Kim} \& \mathrm{Pae}, 2005) 6$ 세 후반 까지는 연령을 6개월 단위로, 7세 이후 는 1년 단위로 나누어 연령 집단을 구성하였다. 전체 연구대상자의 인구통계적 특성은 Table 1 에 제시하였다. 연구대상자의 지역별 분 포는 Figure 1과 같다.

본 연구 대상자는 주양육자나 유치원 및 어린이집 교사의 보고 에 따라 선천적 문제나 의학적 진단이 확인된 아동은 제외하였다. 모든 대상자는 신체적, 인지적, 신경학적 발달 및 정서와 관련된 의 학적인 진단을 받지 않았으며, 청력 및 감각 발달에 문제가 없었다.

전체 대상자는 자음정확도를 기준으로 일반과 말소리장애 집단 으로 분류하였다. 말소리장애 집단은 아동용발음평가(Assessment of Phonology and Articulation for Children, APAC; Kim, Pae, \& Park, 2007)에서 백분위수 16 이하이거나 APAC의 표준화 자료에 규준이 없는 6세 후반-9세 아동은 원점수 3점 이상인 아동으로 구 성하였다. APAC의 표준화 자료에 규준이 없는 2 세 전반 아동은 전 체 대상자에는 포함시켰으나, 말소리장애 여부를 판단하는 것이 모 호하여 일반과 말소리장애 집단별 분석에는 포함하지 않았다. 따 라서 전체 대상자는 2 세 전반 12 명을 제외하고 일반아동 372 명과

Table 1. Participants' demographic characteristics

\begin{tabular}{|c|c|c|c|c|c|c|c|c|c|}
\hline \multirow{2}{*}{ Age (yr;mo) } & \multicolumn{3}{|c|}{ Total participants } & \multicolumn{3}{|c|}{ TD group } & \multicolumn{3}{|c|}{ SSD group } \\
\hline & $\mathrm{N}$ & Boy & Girl & $\mathrm{N}$ & Boy & Girl & N & Boy & Girl \\
\hline $2 ; 0-2 ; 5$ & 12 & 6 & 6 & - & - & - & - & - & - \\
\hline $2 ; 6-2 ; 11$ & 29 & 11 & 18 & 29 & 11 & 18 & - & - & - \\
\hline $3 ; 0-3 ; 5$ & 48 & 26 & 22 & 39 & 20 & 19 & 9 & 6 & 3 \\
\hline $3 ; 6-3 ; 11$ & 37 & 22 & 15 & 23 & 12 & 11 & 14 & 10 & 4 \\
\hline $4 ; 0-4 ; 5$ & 45 & 25 & 20 & 25 & 11 & 14 & 20 & 14 & 6 \\
\hline $4 ; 6-4 ; 11$ & 45 & 22 & 23 & 31 & 13 & 18 & 14 & 9 & 5 \\
\hline $5 ; 0-5 ; 5$ & 41 & 18 & 23 & 32 & 12 & 20 & 9 & 6 & 3 \\
\hline $5 ; 6-5 ; 11$ & 27 & 15 & 12 & 17 & 8 & 9 & 10 & 7 & 3 \\
\hline $6 ; 0-6 ; 5$ & 40 & 21 & 19 & 20 & 8 & 12 & 20 & 13 & 7 \\
\hline $6 ; 6-6 ; 11$ & 47 & 26 & 21 & 35 & 18 & 17 & 12 & 8 & 4 \\
\hline $7 ; 0-7 ; 11$ & 75 & 50 & 25 & 55 & 36 & 19 & 20 & 14 & 6 \\
\hline 8;0-8;11 & 54 & 37 & 17 & 48 & 32 & 16 & 6 & 5 & 1 \\
\hline $9 ; 0-9 ; 11$ & 24 & 12 & 12 & 18 & 9 & 9 & 6 & 3 & 3 \\
\hline Total & 524 & 291 & 233 & 372 & 179 & 164 & 140 & 95 & 45 \\
\hline
\end{tabular}

TD= typically developing children; SSD = children with speech sound disorders
말소리장애 아동 140 명으로 분류되었다(Table 1). 전체 대상자에 다문화가정 아동 25 명도 포함되었는데, 이중 7명은 말소리장애로 판단되었다. 전체 대상자 내 일반과 말소리장애 집단의 연령과 성별 분포는 Table 1 과 같다.

\section{자료 수집}

본 연구 자료는 한국 조음음운프로파일(Korean Articulation Phonology Profile, K-APP; Ha, Kim, \& Seo, in press) 의 표준화 연 구 맥락에서 수집하였다. K-APP은 총 5가지 소검사로 구성되어 있 으며, 그 중 낱말검사의 하위평가 단계로 낱말 산출의 일관성 검사 가 있다. 낱말 산출의 일관성 검사에서는 2 음절에서부터 5 음절까 지의 총 22개 낱말을 검사대상자에게 그림으로 제시한 후 아동의 자발적인 산출을 유도하였다. 검사어는 검사문항 순서대로 1 차적 으로 제시한 후 다시 전체 검사문항을 순서대로 2 회씩 더 제시하였 다. 따라서 검사대상자는 22 개의 낱말을 총 3 번씩 산출하였다. 모 든 연구 자료는 유치원, 어린이집, 지역아동센터 혹은 대상자의 가 정 내에 있는 독립된 방에서 개별적인 검사를 통해 수집하였다. 검 사는 검사방법, 절차 및 지시 문장, 전사 방법에 대해 최소 $1-2$ 회기 훈련을 받은 언어병리학전공 대학원생과 학부생이 실시하였다. 치 간음화, 구개음화, 설측음화 및 기타 왜곡오류에 대해서는 자료 분 석 시 음성 전사에 참조하기 위해 반드시 평가현장에서 표기하도 록 하였다. 모든 아동 반응은 음성녹음기(SONY ICD-PX333)로 녹 음하였다.

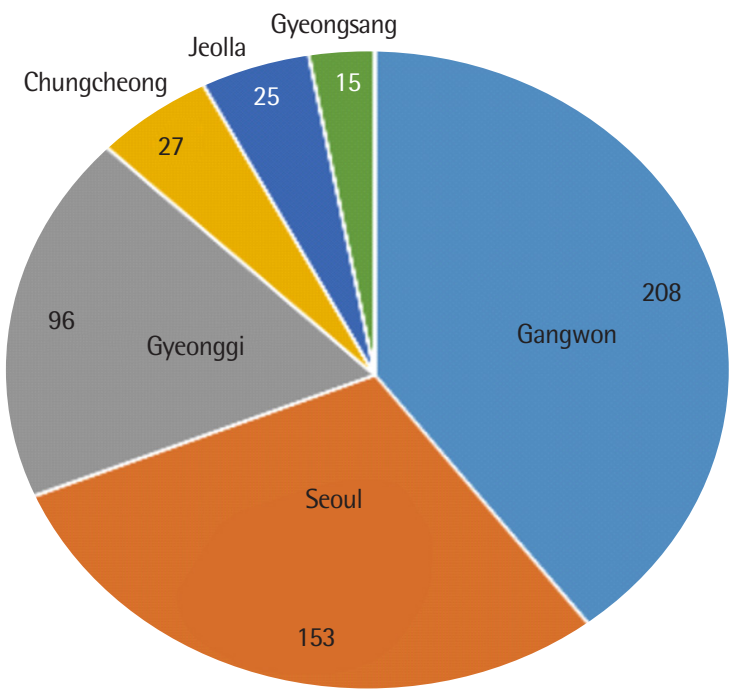

Figure 1. Demographic information of total participants $(\mathrm{N}=524)$. 


\section{자료 전사 및 분석}

아동의 조음 특징과 음성 전사에 대해 집중적인 훈련을 받은 언 어병리학 대학원생 4 명과 제 1 저자가 음성 전사 및 자료 분석을 하 였다. 음성 전사는 치간음화, 설측음화 등 청지각적으로 분명한 왜 곡 오류는 차별적으로 구별하였으나, Holm 등(2007)에 기술된 바 대로 간략 음성 전사(broad phonetic transcription)를 기본으로 하 였다.

음성 전사한 자료를 토대로 일관성 점수를 구하였다. 조음정확 도와상관없이 검사어를 3 회 기회 중 모두 다른 형태로 산출하였다 면 0점, 2회만 동일하게 산출하였다면 1점, 3회 모두 동일하면 2점 으로 처리하였다. 따라서 일관성 점수의 가능한 최고 점수는 44 점 이고, 점수가 높을수록 일관적인 산출을 보이는 것이다.

\section{신뢰도}

전체 자료에서 무작위로 총 30 명의 자료를 선정하여 아동 반응 에 대한 전사 및 분석의 정확성을 판단하기 위해 전사자 간 신뢰도 를 분석하였다. 전체 자료 분석에 참여한 4 명이 독립적으로 음성 전 사를 하고 일관성 점수를 분석하여 신뢰도를 살펴보았다. 음성 전 사 자료에 대한 전사자 간 일치도는 4 명의 전사자를 각각 2 명씩 대 응(총 6쌍)하여 전체 자음 중 전사자 간 일치한 자음의 비율로 살펴 보았는데, 평균 $95.52 \%$ 의 전사자간 일치도를 보였다. 다음으로 Cronbach's alpha를 이용하여 전사 자료를 토대로 평가한 일관성 점수 에 대한 분석자 간 신뢰도를 구했는데, 상관계수는 .953로 통계적 으로 유의하게 나왔다 $(p<.05)$.

Table 2. Consistency scores and ratios of TD and SSD groups

\begin{tabular}{|c|c|c|c|c|c|c|}
\hline \multirow{2}{*}{$\begin{array}{l}\text { Age } \\
\text { (yr;mo) }\end{array}$} & \multicolumn{3}{|c|}{ TD group } & \multicolumn{3}{|c|}{ SSD group } \\
\hline & N & $\begin{array}{l}\text { Consistency } \\
\text { score }\end{array}$ & $\begin{array}{c}\text { Consistency } \\
\text { ratio }\end{array}$ & $\mathrm{N}$ & $\begin{array}{l}\text { Consistency } \\
\text { score }\end{array}$ & $\begin{array}{c}\text { Consistency } \\
\text { ratio }\end{array}$ \\
\hline $2 ; 6-2 ; 11$ & 29 & 34.48 (9.30) & 78.37 (21.13) & - & - & - \\
\hline $3 ; 0-3 ; 5$ & 39 & $37.90(6.04)$ & $86.13(13.72)$ & 9 & $31.89(7.93)$ & 72.47 (18.02) \\
\hline 3;6-3;11 & 23 & 38.87 (4.38) & 88.34 (9.96) & 14 & $31.93(10.12)$ & 72.56 (23.00) \\
\hline $4 ; 0-4 ; 5$ & 25 & $40.60(2.96)$ & 92.27 (6.72) & 20 & 35.75 (6.14) & 81.25 (13.97) \\
\hline $4 ; 6-4 ; 11$ & 31 & $41.19(2.83)$ & 93.62 (6.44) & 14 & 36.79 (6.62) & 83.60 (15.05) \\
\hline $5 ; 0-5 ; 5$ & 32 & 41.34 (2.43) & 93.96 (5.53) & 9 & $37.33(2.50)$ & 84.85 (5.68) \\
\hline $5 ; 6-5 ; 11$ & 17 & 40.41 (3.02) & 91.84 (6.87) & 10 & 38.00 (3.94) & 86.36 (8.96) \\
\hline $6 ; 0-6 ; 5$ & 20 & 40.80 (3.32) & 92.73 (7.54) & 20 & $39.00(5.47)$ & 88.64 (12.43) \\
\hline $6 ; 6-6 ; 11$ & 35 & 41.89 (2.06) & 95.19 (4.67) & 12 & 40.92 (3.42) & 92.99 (7.78) \\
\hline $7 ; 0-7 ; 11$ & 55 & 42.56 (2.09) & $96.74(4.75)$ & 20 & 39.35 (5.23) & 89.43 (11.90) \\
\hline 8;0-8;11 & 48 & 43.21 (1.44) & 98.20 (3.28) & 6 & 39.50 (5.54) & 89.77 (12.59) \\
\hline $9 ; 0-9 ; 11$ & 18 & $42.56(2.66)$ & 96.72 (6.05) & 6 & 41.00 (3.69) & 93.18 (8.38) \\
\hline Total & 372 & 40.69 (4.63) & $92.48(10.52)$ & 140 & 37.29 (6.51) & 84.76 (14.79) \\
\hline
\end{tabular}

Values are presented as mean (SD).

$\mathrm{TD}=$ typically developing children; SSD = children with speech sound disorders.

\section{통계 분석}

일반과 말소리장애 아동 집단과 연령에 따라 차이를 나타내는지 살펴보기 위해 이원분산분석(two-way ANOVA)을 실시하였다. 이 후 사후분석은 Bonferroni 검정을 실시하였으며 모든 유의 수준은 $p<.05$ 로 설정하였다.

기준점(norm-reference criterion) 선정방법으로 전체 점수의 상 대적 서열을 나타내는 백분위수(percentile)를 이용하여 정상적인 변이성과 병리적인 비일관성을 구분하는 기준점을 결정하고자 하 였다. 전체 백분위수 자료를 근거해서 통계적으로 하위 5\%는 95\% 신뢰구간에서 벗어나는 특이한 값 즉 통계적으로 유의한 수준의 확률이므로 하위 $5 \%$ 는 정상적인 변이성의 $95 \%$ 를 벗어나는 비율 이므로 병리적인 비일관성으로 판단할 수 있겠다.

\section{연구결과}

\section{일반아동과 말소리장애 아동의 일관성 점수}

2 세 후반부터 9 세 일반과 말소리장애 아동의 연령에 따른 일관 성 점수 및 비율의 기술통계치는 Table 2 와 같다. 일반과 말소리장 애 집단의 연령에 따른 일관성 점수의 변화는 Figure 2 와 같다. 먼 저 일반아동은 2 세 후반에 일관성 점수(가능한 최고점수: 44 점)가 34.48 (78.37\%)였으며 3세 전반이 되면 37.90 (86.13\%)으로 증가하 였다. 이 후 연령이 증가할수록 점진적으로 증가하여 7세 이후에는 일관성 점수가 $42.5(96.74 \%)$ 이상이 되었다. 말소리장애 아동은 일 관성 점수가 각각 31.89 와 31.93 인 3세 전반과 후반을 비롯해서 모 든 연령대에서 일반아동보다 점수가 낮았으나, 일반아동과 마찬가 지로 연령이 증가할수록 증가하는 경향성을 보였다.

이원분산분석 결과, 집단 $\left(F_{(1,489)}=51.239, p<.001, \eta_{\mathrm{p}}{ }^{2}=.095\right)$ 과 연령 $\left(F_{(11,489)}=11.993, p<.001, \eta_{p}{ }^{2}=.212\right)$ 에 따른 유의한 차이는 보

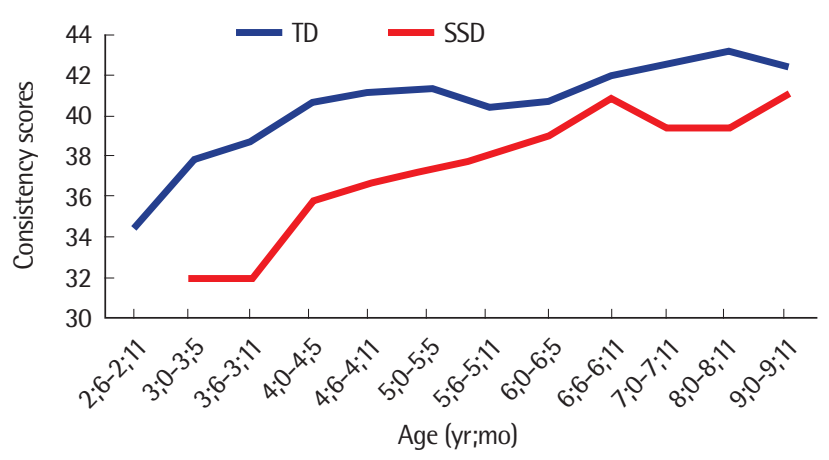

Figure 2. Consistency scores of typically developing children (TD) and children with speech sound disorders (SSD) across ages. 
Table 3. Consistency scores and ratios of total participants

\begin{tabular}{lccc}
\hline Age $(y r ; m o)$ & $N$ & Consistency score & Consistency ratio \\
\hline $2 ; 0-2 ; 5$ & 12 & $36.50(8.19)$ & $82.95(18.60)$ \\
$2 ; 6-2 ; 11$ & 29 & $34.48(9.30)$ & $78.37(21.13)$ \\
$3 ; 0-3 ; 5$ & 48 & $36.77(6.77)$ & $83.57(15.38)$ \\
$3 ; 6-3 ; 11$ & 37 & $36.24(7.77)$ & $82.37(17.66)$ \\
$4 ; 0-4 ; 5$ & 45 & $38.44(5.20)$ & $87.37(11.82)$ \\
$4 ; 6-4 ; 11$ & 45 & $39.82(4.76)$ & $90.51(10.83)$ \\
$5 ; 0-5 ; 5$ & 41 & $40.46(2.94)$ & $91.96(6.69)$ \\
$5 ; 6-5 ; 11$ & 27 & $39.52(3.52)$ & $89.81(8.01)$ \\
$6 ; 0-6 ; 5$ & 40 & $39.90(4.56)$ & $90.68(10.36)$ \\
$6 ; 6-6 ; 11$ & 47 & $41.64(2.47)$ & $94.63(5.62)$ \\
$7 ; 0-7 ; 11$ & 75 & $41.71(3.50)$ & $94.79(7.96)$ \\
$8 ; 0-8 ; 11$ & 54 & $42.80(2.48)$ & $97.26(5.63)$ \\
$9 ; 0-9 ; 11$ & 24 & $42.17(2.94)$ & $95.83(6.69)$ \\
Total & 524 & $39.69(5.51)$ & $90.20(12.52)$ \\
\hline
\end{tabular}

Values are presented as mean (SD).

였으나 집단과 연령 간 상호작용은 유의하지 않았다. 연령에 대한 사후검정 결과, 2 세 후반은 4 세 전반 이후 모든 연령대와 유의미한 차이를 보였다. 그 외 3 세 전반은 5 세 전반과 6 세 후반 이후 연령대 와 유의한 차이를 보였으며 3세 후반은 5세 전반과 6세 전반 이후 연령대와 유의한 차이를 보였다 $(p<.05)$. 그 외에 4 세 전반은 7,8 세 와 4 세 후반은 3 세 후반 연령과 유의한 차이를 보였다 $(p<.05)$. 사 후검정결과를 요약하면 2 세 후반과 3 세 전· 후반이 연령이 높은 아 동들과 뚜렷한 차이를 보이면서 일관성 점수가 낮다가 4 세 후반에 이르면 높은 연령대와 유의한 차이가 없는 일관성을 갖추었다.

\section{전체 대상자의 일관성 점수 및 비일관적인 말소리장애 진단 기준점}

전체 대상자를 모두 포함하여 연령별 일관성 점수의 평균 및 표 준편차는 Table 3 과 같다. 전체와 연령별 일관성 점수의 $5,25,50$, 75,95 백분위수는 Table 4 와 같다. 전체 대상자와 연령별 일관성 점 수의 백분위수는 Appendix 1에 기재하였다. 2 세 전반을 포함한 전 체 대상자 일관성 점수에서 특이사항으로 2 세 전반이 2 세 후반에 비해서 일관성 점수가 높게 나타나, $5,25,50$ 백분위수에 해당하는 점수가 2 세 후반보다 높았다. 이러한 결과는 변이성 검사를 끝까지 마친 아동만이 본 연구 자료에 포함될 수 있었기 때문에 2 세 전반 아동 집단은 상대적으로 말·언어능력이 양호하거나 평균 이상인 아동으로만 구성된 것과 관련이 있다.

연령별 백분위수표에서 하위 $5 \%$ 에 해당하는 일관성 점수를 자 세히 살펴보면(Table 4), 2세 후반이 17점으로 가장 낮은 것으로 나 타났고, 연령이 증가함에 따라 점진적으로 증가하여 4 세 후반부터
Table 4. Percentile values of consistency scores

\begin{tabular}{lrlllll}
\hline \multirow{2}{*}{ Age $(\mathrm{yr} ; \mathrm{mo})$} & $\mathrm{N}$ & \multicolumn{5}{c}{ Percentile } \\
\cline { 3 - 7 } & & 5 th & 25 th & 50 th & 75 th & 95 th \\
\hline $2 ; 0-2 ; 5$ & 12 & 26 & 27.50 & 39.50 & 44 & 44 \\
$2 ; 6-2 ; 11$ & 29 & 17 & 25.50 & 36.00 & 44 & 44 \\
$3 ; 0-3 ; 5$ & 48 & 21.90 & 32.25 & 37.50 & 44 & 44 \\
$3 ; 6-3 ; 11$ & 37 & 20 & 32 & 38 & 43 & 44 \\
$4 ; 0-4 ; 5$ & 45 & 26.50 & 35 & 40 & 42.50 & 44 \\
$4 ; 6-4 ; 11$ & 45 & 28.10 & 38 & 41 & 43.50 & 44 \\
$5 ; 0-5 ; 5$ & 41 & 34.10 & 38.50 & 41 & 43 & 44 \\
$5 ; 6-5 ; 11$ & 27 & 32.20 & 37 & 41 & 42 & 44 \\
$6 ; 0-6 ; 5$ & 40 & 29.05 & 38.25 & 41 & 44 & 44 \\
$6 ; 6-6 ; 11$ & 47 & 36.20 & 41 & 42 & 43 & 44 \\
$7 ; 0-7 ; 11$ & 75 & 33.40 & 41 & 43 & 44 & 44 \\
$8 ; 0-8 ; 11$ & 54 & 38.50 & 42.75 & 44 & 44 & 44 \\
$9 ; 0-9 ; 11$ & 24 & 34.50 & 41.25 & 44 & 44 & 44 \\
Total & 524 & 27 & 38 & 42 & 44 & 44 \\
\hline
\end{tabular}

는 28.1점부터 38.5점까지로, 하위 $5 \%$ 아동도 상당히 높은 일관성 점수를 보이는 것으로 나타났다. 2 세 전.후반을 포함해서 대부분 의 연령대에서 22 개의 낱말을 모두 동일한 형태로 발음하여 비일관 성 점수가 44 점 만점인 아동이 75 백분위수 이상에 해당하였다.

전체 대상자로부터 분석된 비일관성 점수의 $5,25,50$ 백분위수 는 각각 $27,38,42$ 점이였으며 69 백분위수 이상(Appendix 1)은 44 점인 것으로 나타났다. 전체 대상자 자료를 바탕으로 정상적인 변 이성과 병리적인 비일관성을 나누는 일관성 점수의 기준점을 찾는 다면 정상적인 변이성의 $95 \%$ 를 벗어나는 비율인 하위 $5 \%$ 에 해당 하는 27점을 제안할 수 있다. 따라서 연령에 상관없이 아동이 27점 미만으로 일관성 점수를 받는다면 발달적 변이성의 경계를 넘은 비 일관적인 말소리장애로 진단할 수 있다. 규준의 하위 $5 \%$ 에 해당하 는 27 점을 토대로 총 140 명의 말소리장애 아동 가운데 비일관적인 말소리장애로 진단되는 아동은 12 명인 것으로 나타났다.

\section{논의 및 결론}

본 연구는 일반과 말소리장애 아동을 대상으로 낱말 산출의 일 관성 점수를 구한 후 집단과 연령에 따라 어떠한지 비교함으로써 일반과 말소리장애의 발달적 특성을 살펴보고, 비일관적 말소리장 애를 진단할 수 있는 기준점을 찾고자 하였다. 2 세 후반부터 9 세까 지 일반과 말소리장애 아동의 연령에 따른 일관성 점수를 살펴본 결과, 집단과 연령에 따른 유의한 차이가 나타났으며 상호작용은 유의하지 않았다. 일반아동의 경우 2 세 후반은 일관성 점수가 평균 34점(78\%)으로 가장 낮은 점수를 보이면서 높은 연령대와 뚜렷한 
차이를 보였다. 3-4세에 점진적으로 꾸준히 일관성 점수가 증가하 여 4세 후반에 이르면 평균 41점대(94\%)가 되면서 이후 높은 연령 대와 비슷한 일관성을 보였다. 이러한 연구결과는 연령이 증가하면 서 아동이 일관적인 산출을 보이며 특히 3-4세에 일관성이 유의하 게 증가한다는 국내외 선행연구 결과와 일치한다(Burt, Holm, \& Dodd, 1999; Dodd, 1995; Holmes et al., 2007; Hwang \& Ha, 2012; Kenney \& Prather, 1986; Teitzel \& Ozanne, 1999; Williams \& Stackhouse, 2000). 선행연구 중 본 연구와 가장 비슷한 연구인 Dodd (1995)와 Holm 등(2007)은 25개의 낱말 리스트를 이용하여 3세부 터 6세 영국 아동 409명을 대상으로 대규모 횡단 자료를 진행하여 비일관성 점수를 구하였다. 본 연구와 동일하게 낱말당 3 번의 산출 기회를 주었지만 분석방법은 다소 다르게 전체 낱말 중 3 번의 산출 기회 중 한번이라도 다른 형태로 발음한 단어의 비율을 구하였다. 즉 본 연구에서 사용한 2 점 체계를 바탕으로 구한 ‘일관성 점수’와 는 다르게 1 점 체계로 '비일관성 점수'를 구하였다. 또한 아동의 반 응에 대한 질적 분석을 부가적으로 하였는데 3 번 모두 다른 형태로 모두 오조음한 경우로부터 정반응과 오반응이 혼합된 변이적인 산 출을 구분하였다. 아동이 동일한 낱말을 오조음하기도 하지만 정 조음도 하면서 다양한 형태로 목표낱말을 산출할 경우 아동이 음 운 체계의 변화를 겪고 성장하고 있음을 의미한다고 긍정적으로 해석하였다. Dodd (1995)와 Holm 등(2007)의 연구 결과, 연구대상 자 중 가장 나이가 어린 3 세가 가장 변이적인 산출 형태를 보였으나 비일관성 비율이 $13 \%$ 로 낮았으며, 변이적인 반응의 대부분도 정조 음과 오조음이 혼합된 것으로 나타나 발달적 변이성의 특징을 보였 다. 또한 아동이 4 세 6 개월에 이르면 단어의 $95 \%$ 이상을 동일한 형 태로 발음하여 변이적인 산출이 거의 사라졌다. 이러한 4 세 후반 일 반아동의 결과는 앞서 언급한 본 연구결과와 거의 일치하고 있으며, 변이적 낱말 산출에 대한 발달 특성을 제시하고 있다.

Dodd (1995)는 3세부터 6세 영국아동의 표준화 자료를 토대로 비일관적인 말소리장애의 진단 기준을 제안하였다. 연구자는 표준 화 자료에서 가장 변이적인 산출을 보였던 3세 전반의 비일관성 평 균점수(12.96\%)에서 표준편차 2.5 에 해당하는 비율인 $40 \%$ 을 기준 점으로 제시하였다. 이후 Dodd와 동료들은 여러 연구를 통해 이 점수를 기준으로 비일관적인 말소리장애로 진단된 아동의 비일관 성은 발달적 변이성과는 양과 질적인 면에서 다르고, 어떠한 연령 대에서도 관찰이 안 되는 병리적인 특징이라는 것을 보여주었다 (Dodd \& Bradford, 2000; Holm et al., 2007). 본 연구는 Dodd (1995) 를 참조하여 자료 수집과 분석을 진행하였다. 하지만 여러가지 면 에서 선행연구와 차이점이 있다. 먼저 2음절부터 5음절까지 점진적 으로 낱말의 길이가 길어지고 음운구조가 복잡해지는 22 개의 검
사어를 이용하여 단어당 2 점의 채점 방식으로 비일관성이 아닌 일 관성 점수를 구하였다. 또한 발달적 변이성을 두드러지게 보이는 2 세 전-후반 아동을 포함하였으며, 정상적으로 정확하고 일관성 산 출을 보이는 일반아동뿐만 아니라 말소리장애 아동 140 명의 자료 도 규준에 포함하였다. 연령과 집단 간 일관성 점수의 차이를 살펴 보고자 실시한 이원분산분석 결과 집단 간 일관성 점수가 유의한 차이를 보이나 일반과 말소리장애 아동 집단은 서로 비슷한 발달 패턴을 보였다. 또한 말소리장애 아동 중 일부만이 비일관적인 말소 리장애로 분류되는 선행연구 결과와 임상경험을 고려한다면 규준 자료에 140 명의 말소리장애 아동을 포함하는 것이 타당하다. 즉 어 린 연령대에서 보편적으로 관찰되는 발달적 변이성으로부터 병리 적인 비일관성을 구분하고, 동시에 말소리장애 중 비일관적인 장애 를 감별 진단할 수 있는 일관성 점수의 기준점을 찾기 위해서는 일 반과 말소리장애를 모두 포함한 전체 아동 자료가 준거집단(criterion group)으로 보다 더 타당한 표준화 자료라 할 수 있다.

본 연구에서는 전체 대상자의 백분위수 자료에서 하위 $5 \%$ 에 해 당하는 27점을 정상적인 변이성과 병리적인 비일관성을 구분하는 일관성 점수의 기준점으로 제안하였다. 즉 3 회씩 산출하는 22 개의 낱말 검사에서 연령에 상관없이 아동이 27점 미만으로 일관성 점 수를 받는다면 발달적 변이성의 경계를 넘어 선 비일관적인 말소리 장애로 진단할 수 있겠다. 흥미롭게도 전체 일관성 점수 44 점에서 27점은 약 61.3\%에 해당하는 점수로 Dodd (1995)의 '비일관성 점 수’ $40 \%$ 와 거의 동일한 수준이다. 또한 27점의 기준점을 사용하여 본 연구에 포함된 말소리장애 아동을 살펴보면 총 140 명 중 12 명 (8.6\%)을 비일관적인 말소리장애로 진단할 수 있다. 이러한 비일관 적 말소리장애 비율은 전체 말소리장애 아동 중 비일관적 말소리 장애가 약 $9 \%$ 를 차지하였다는 영국 자료(Broomfield \& Dodd, 2004) 와 거의 비슷한 수치를 보여, 선행연구와 비교하여 본 연구의 기준 점이 타당하다는 것을 제안하고 있다. 요컨대 본 연구에서 비일관 적 말소리장애를 진단하기 위한 기준점으로 제안된 '일관성 점수' 27점은 영국의 표준화 연구 자료와 함께 조음변이성과 비일관성에 대한 보편적인 특성과 경향을 반영한다고 할 수 있겠다.

비일관적인 말소리장애는 말 처리 과정에서 광범위한 어려움으 로 인해 발생하거나, 하나의 근본적인 결함으로 인해 여러 단계에 서 어려움을 보일 수 있다(Holm et al., 2007). 먼저 낱말 산출을 위 한 음운 계획이 구체적이지 않거나, 음운 계획상의 결함으로 인해 비일관성을 보일 수 있다(Bradford-Heit \& Dodd, 1998; Bradford \& Dodd, 1994; Chiat, 1983). 이러한 음운 계획상의 문제는 단어의 음운표상이 정확하지 않거나, 정확한 음운표상으로 접근하는 것 에 문제나 음운 계획을 세우는 것의 어려움으로 인해 비롯된 것일 
수도 있다(Griffiths \& Snowling, 2002). 또한 불완전한 음운 계획 은 부정확한 말·운동프로그램으로 이어지고, 부정확한 말 움직임 을 일으키게 된다(Ozanne, 1995). 이러한 말 처리 과정상에 보이는 광범위한 결함으로 인해 비일관적 말소리장애는 다른 말소리장애 하위유형에 비해 언어의 의미, 구문, 문법 영역에서 어려움을 보이 는 아동과 음운인식과 읽기상의 문제를 보이는 아동의 비율이 높 다(Dodd, 2005).

비일관적인 낱말 산출에 대한 연구는 말 처리 과정과 말소리장 애에 대한 근본적인 이해를 넓히는데 기여하지만 궁극적으로 임상 에 시사하는 바가 크다. 비일관적인 조음 산출을 보일 경우 비슷한 정확도를 보이는 아동과 비교해 말 명료도가 훨씬 떨어져 의사소 통상의 문제를 더 크게 보일 수 있다(Macrae, Tyler, \& Lewis, 2014). 낱말의 비일관적인 산출 정도가 높을수록 아동이 음소 간 차이를 구별하면서 다양한 음소를 습득하는 것이 어렵고, 지속적으로 말 소리 문제를 보일 가능성이 높다(Forrest, Elbert, \& Dinnsen, 2000). 또한 비일관적인 오류를 보이는 경우에는 아동의 오류를 음운패턴 또는 규칙으로 설명하기 어려워 치료 목표를 잡는 것이 어렵고, 아 동이 목표음소를 학습하고 일반화하는 과정이 느리게 진행된다. 비일관적인 말소리장애를 대상으로 치료 효과를 살펴본 연구는 이 아동들에게는 일반적인 음운장애와는 다르게 음운대조기법이 효 과적이지 않고 핵심어휘기법과 같이 정확성 보다는 일관성을 중재 목표로 하는 것이 효과적이라 제안하였다(Crosbie, Holm, \& Dodd, 2005; Dodd \& Bradford, 2000). 따라서 낱말 산출의 일관성 여부는 아동의 말 특징 및 진단뿐만 아니라, 적절한 치료법 선택과 치료 예 후에 대해 시사하는 바가 크기 때문에 말소리장애 평가 시 조음정 확도와함께 반드시 살펴볼 필요가 있다.

본 연구는 말소리장애 감별 진단을 목적으로 아동의 말소리 산 출능력과 관련된 전체적인 정보를 포함한 프로파일을 제공하기 위 해 개발된 검사도구의 표준화 연구 맥락에서 진행되었다. 본 연구 에서 제시한 비일관적인 말소리장애를 진단하는 기준점은 문헌조 사와 표준화 자료의 통계적 검증을 토대로 제안되었지만, 지속적인 연구를 통해 실제 임상에서 발달적인 변이성과 병리적인 비일관성 의 경계를 잘 구분하여 타당하게 비일관적인 음운장애를 감별 진 단할 수 있는지 검증해야 할 것이다. 비일관적인 말소리장애를 진 단할 때 기준점의 민감도와 특이도는 어떠한지 살펴봄으로써 기준 점의 타당성을 검증하고 더 나아가 이 기준을 사용한 말소리장애 하위유형 분류 체계의 적절성을 검증하고, 하위유형별 특징을 연 구해야할 것이다.

\section{REFERENCES}

Bradford-Heit, A., \& Dodd, B. (1998). Learning new words using imitation and additional cues: differences between children with disordered speech. Child Language Teaching and Therapy, 14(2), 159-179.

Bradford, A., \& Dodd, B. (1994). The motor planning abilities of phonologically disordered children. European Journal of Disorders of Communication, 29(4), 349-369.

Broomfield, J., \& Dodd, B. (2004). The nature of referred subtypes of primary speech disability. Child Language Teaching and Therapy, 20(2), 135-151.

Burt, L., Holm, A., \& Dodd, B. (1999). Phonological awareness skills of 4-yearold British children: an assessment and developmental data. International Journal of Language \& Communication Disorders, 34(3), 311-335.

Chiat, S. (1983). Why Mikey's right and my key's wrong: the significance of stress and word boundaries in a child's output system. Cognition, 14(3), 275-300.

Crosbie, S., Holm, A., \& Dodd, B. (2005). Intervention for children with severe speech disorder: a comparison of two approaches. International Journal of Language \& Communication Disorders, 40(4), 467-491.

Dodd, B. (1995). Differential diagnosis and treatment of children with speech disorder. London: Whurr.

Dodd, B. (2005). Differential diagnosis and treatment of children with speech disorder (2nd ed.). London: Whurr.

Dodd, B., \& Bradford, A. (2000). A comparison of three therapy methods for children with different types of developmental phonological disorder. International Journal of Language \& Communication Disorders, 35(2), 189209.

Dyson, A. T., \& Paden, E. P. (1983). Some phonological acquisition strategies used by two-year-olds. Journal of Childhood Communication Disorders, 7(1), 6-18.

Forrest, K., Elbert, M., \& Dinnsen, D. A. (2000). The effect of substitution patterns on phonological treatment outcomes. Clinical Linguistics \& Phonetics, 14(7), 519-531.

Griffiths, Y. M., \& Snowling, M. J. (2002). Predictors of exception word and nonword reading in dyslexic children: the severity hypothesis. Journal of Educational Psychology, 94(1), 34-43.

Grunwell, P. (1981). The nature of phonological disability in children. London: Academic Press.

Grunwell, P. (1992). Processes of phonological change in developmental speech disorders. Clinical Linguistics \& Phonetics, 6(1-2), 101-122. 
Ha, J. W., Kim, S. J., Kim, Y. T., \& Shin, M. (2019). Developmental analysis in Korean children's speech production using percentage of consonants correct and whole-word measurements. Communication Sciences \& Disorders, 24(2), 469-477.

Ha, S, Kim, M., \& Seo, D. (in press). Korean Articulation Phonology Profile. Seoul: Human Brain Research and Consulting.

Ha, S., Kim, M., \& Pi, M. (2019). Percentage of consonants correct and age of acquisition of consonants in Korean-speaking children in one-syllable word contexts. Communication Sciences \& Disorders, 24(2), 460-468.

Han, E. J., \& Ha, J. W. (2017). Variability of speech sound production according to phonetic complexity in children with and without speech sound disorders. Communication Sciences \& Disorders, 22(4), 772-783.

Holm, A., Crosbie, S., \& Dodd, B. (2007). Differentiating normal variability from inconsistency in children's speech: normative data. International Journal of Language \& Communication Disorders, 42(4), 467-486.

Hwang, J., \& Ha, S. (2012). A study of articulatory variation in typically developing children between 2 and 4 years of age. Korean Journal of Communication \& Disorders, 17(3), 403-413.

Kenney, K. W., \& Prather, E. M. (1986). Articulation development in preschool children: consistency of productions. Journal of Speech, Language, and Hearing Research, 29(1), 29-36.

Kim, H. Y., \& Ha, S. (2016). Articulatory variability in 24-to 36-month-old typically developing children. Communication Sciences \& Disorders, 21(2), 333-342.

Kim, M. J., \& Pae, S. (2005). The percentage of consonants correct and the ages of consonantal acquisition for 'Korean-Test of Articulation for Children (K-TAC)'. Speech Sciences, 12(2), 139-149.
Kim, M. J., Pae, S., \& Park, C. I. (2007). Assessment of Phonology and Articulation for Children (APAC). Incheon: Human Brain Research \& Consulting Co.

Kim, Y. T. (1996). A study of percentage of correct consonant in 2-6 years through picture articulation test. Korean Journal of Communication \& Disorders, 1, 7-33.

Macrae, T., Tyler, A. A., \& Lewis, K. E. (2014). Lexical and phonological variability in preschool children with speech sound disorder. American Journal of Speech-Language Pathology, 23(1), 27-35.

McLeod, S., \& Hewett, S. R. (2008). Variability in the production of words containing consonant clusters by typical 2-and 3-year-old children. Folia Phoniatrica et Logopaedica, 60(4), 163-172.

Ozanne, A. (1995). The search for developmental verbal dyspraxia. In B. Dodd (Ed.), Differential diagnosis and treatment of children with speech disorder (pp. 91-109). London: Whurr.

Sosa, A. V. (2015). Intraword variability in typical speech development. American Journal of Speech-Language Pathology, 24(1), 24-35.

Sosa, A. V., \& Stoel-Gammon, C. (2006). Patterns of intra-word phonological variability during the second year of life. Journal of Child Language, 33(1), 31-50.

Teitzel, T., \& Ozanne, A. (1999). The development of consistency of speech production. Proceedings of the 20th Annual Child Phonology Conference, Bangor, Wales.

Williamss, P., \& Stackhouse, J. (2000). Rate, accuracy and consistency: diadochokinetic performance of young, normally developing children. Clinical Linguistics \& Phonetics, 14(4), 267-293. 


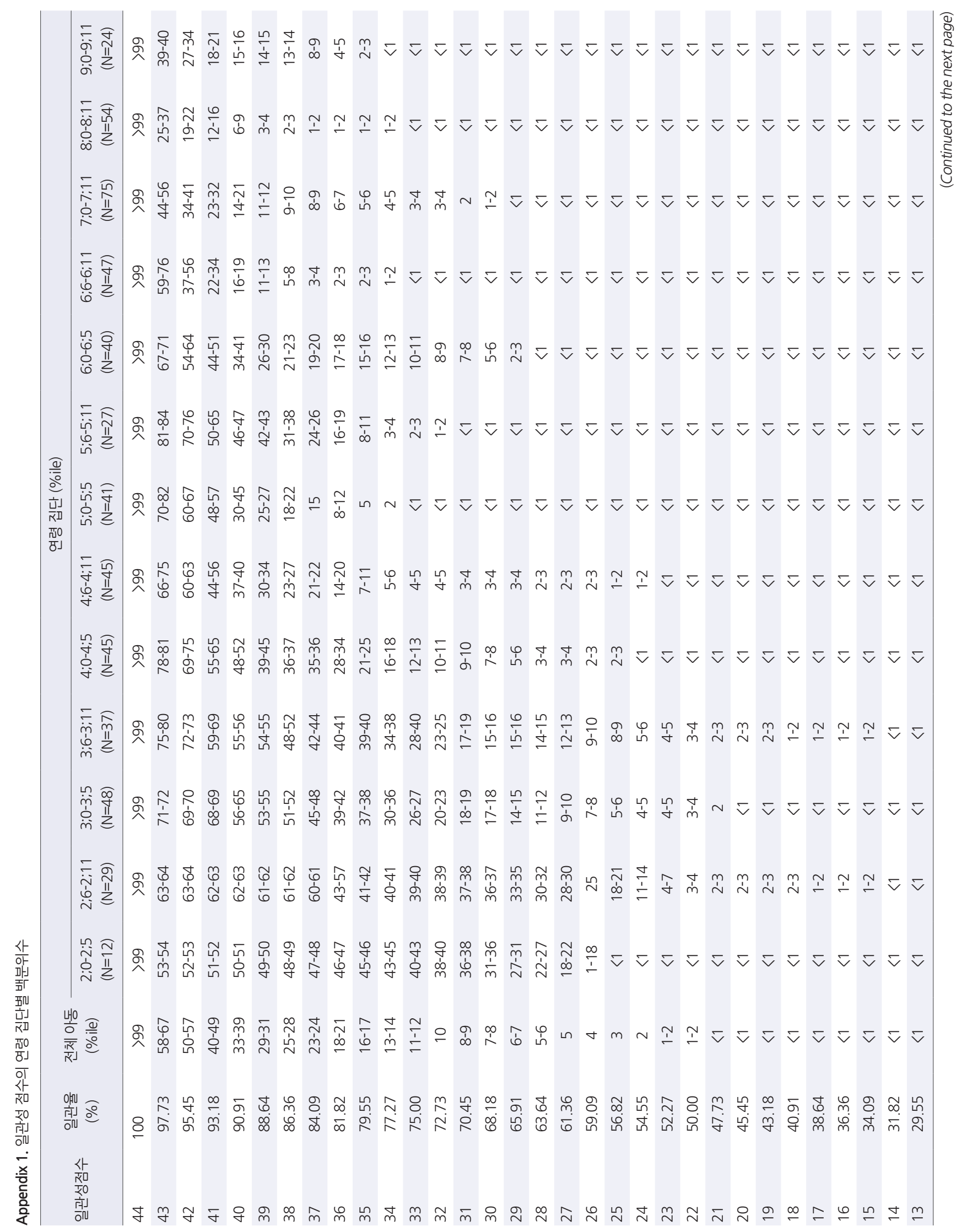




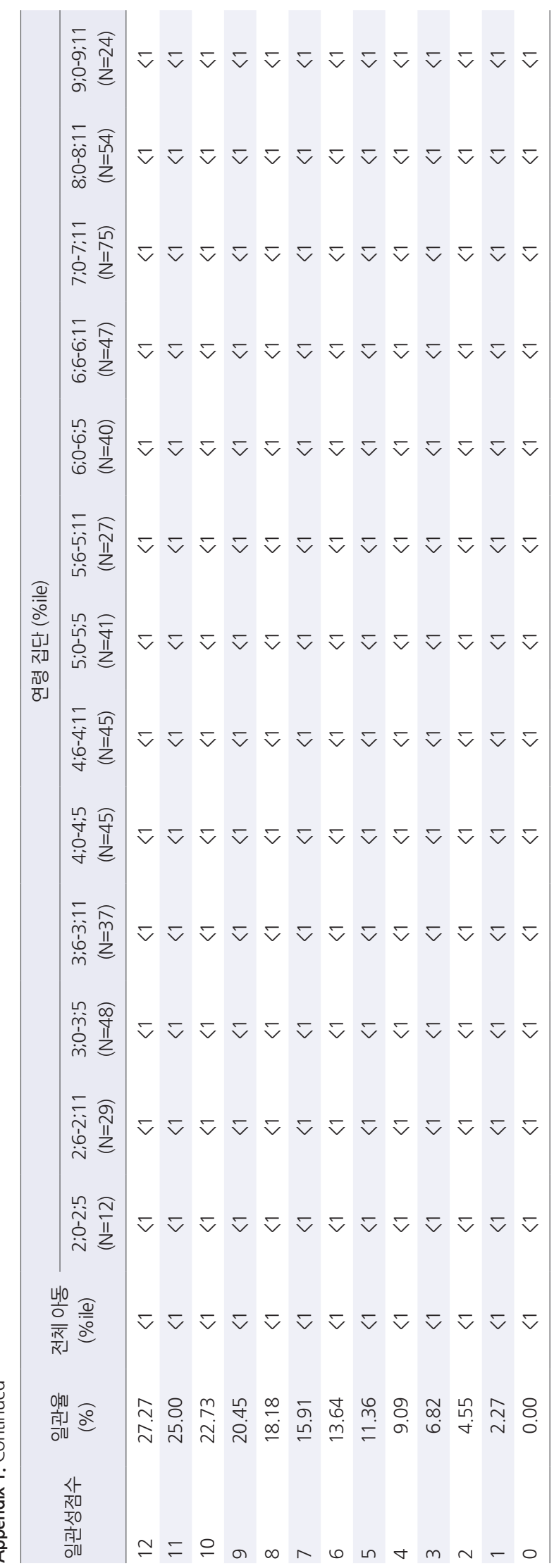




\section{국문초록}

\section{말소리장애 감별 진단을 위한 조음 일관성 연구}

하승희' $\cdot$ 서동기 ${ }^{2}$

'한림대학교 언어청각학부, 한림청각언어연구소, ${ }^{2}$ 한림대학교 심리학과

배경 및 목적: 일반아동과 말소리장애 아동을 대상으로 조음 일관성의 발달 패턴과 특징을 살펴보고, 비일관적인 말소리장애를 감별 진단할 수 있는 점수 체계와 기준점을 제시하고자 하였다. 방법: 2 세 전반에서부터 9 세까지의 일반 또는 말소리장애 아동 524 명을 대상 으로 22 개의 낱말을 3 번씩 산출하게 한 뒤 조음 일관성 점수를 구하였다. 연령과 집단에 따라 조음 일관성 점수가 어떠한지 살펴보고 전 체 대상자의 일관성 점수를 토대로 비일관적 말소리장애 집단을 진단할 수 있는 기준점을 찾고자 하였다. 결과: 연령과 집단에 따라 일 관성 점수가 유의한 차이를 보였으며, 상호작용은 통계적으로 유의하지 않았다. 일반과 말소리장애 아동 모두 연령이 증가함에 따라 정 확하고 일관된 조음을 보였다. 특히 3-4세 사이에 일관성 점수가 유의하게 증가하여 2-3세 아동과 4-6세 아동의 구별된 조음 일관성을 보였다. 전체 대상자의 일관성 점수 백분위수 자료를 토대로 본 연구에서 사용한 검사도구를 사용하여 비일관적인 말소리장애를 진단 할 때 참조할 수 있는 규준을 제안하였다. 하위 $5 \%$ 에 해당하는 27 점을 발달적 변이성과 병리적인 비일관성을 구분하는 기준점으로 정 하였다. 논의 및 결론: 본 연구는 말소리장애의 하위유형을 구별하여 진단할 수 있는 기반을 마련하였으며, 제안된 기준점이 비일관적 인 말소리장애를 포함하여 말소리장애 하위유형을 정확하고 타당하게 구별하는지 추후 검증해야 한다.

핵심어: 말소리장애, 감별진단, 조음 일관성, 비일관적인 말소리장애, 일관성 점수, 기준점

본 연구는 한림대학교 교비학술연구과제(No. HRF-201909-015)에 의해 수행되었음.

\section{참고문헌}

김민정, 배소영(2005).아동용 조음검사를 이용한 연령별 자음정확도와 우리말 자음의 습득연령. 음성과학, 12(2), 139-149.

김민정, 배소영, 박창일(2007). 아동용 발음평가(APAC). 인천: 휴브알앤씨.

김영태(1996). 그림자음검사를 이용한 취학전 아동의 자음정확도 연구. 말-언어장애연구, 1, 7-33.

김희윤, 하승희(2016). 24-36개월 아동의 조음 변이성 연구. Communication Sciences \& Disorders, 21(2), 333-342.

하승희, 김민정, 서동기(출판중). 한국 조음음운프로파일(K-APP). 서울: 휴브알앤씨.

하승희, 김민정, 피민경(2019). 일음절 낱말 과제에서 살펴본 한국 아동의 자음정확도와 습득 연령. Communication Sciences \& Disorders, 24(2), $460-468$.

하지완, 김수진, 김영태, 신문자(2019). 자음정확도와단어단위 음운지표를 이용한 일반아동의 말소리 산출능력에 대한 발달 연구. Communication

Sciences \& Disorders, 24(2), 469-477.

한은지, 하지완(2017). 말소리장애 아동과 일반 아동의 조음복잡성에 따른 조음변이성 연구. Communication Sciences \& Disorders, 22(4), 772-783. 황진경, 하승희(2012). 2세 후반-4세 아동의 조음 변이성 연구. 언어청각장애연구, 17(3), 403-413.

\section{ORCID}

하승희(제1저자, 교신저자, https://orcid.org/0000-0003-2133-3720); 서동기(공동저자, https://orcid.org/0000-0002-3049-5556) 